University of Nebraska - Lincoln

DigitalCommons@University of Nebraska - Lincoln

2004

ECOLOGICAL EFFECTS OF TRANSGENIC CROPS AND THE ESCAPE OF TRANSGENES INTO WILD POPULATIONS

Diana Pilson

Holly R. Prendeville

Follow this and additional works at: https://digitalcommons.unl.edu/bioscifacpub

Part of the Biology Commons

This Article is brought to you for free and open access by the Papers in the Biological Sciences at

DigitalCommons@University of Nebraska - Lincoln. It has been accepted for inclusion in Faculty Publications in the Biological Sciences by an authorized administrator of DigitalCommons@University of Nebraska - Lincoln. 


\title{
Ecological Effects of Transgenic Crops AND THE ESCAPE OF TransGenes INTO WiLd Populations
}

\author{
Diana Pilson and Holly R. Prendeville \\ School of Biological Sciences, University of Nebraska, Lincoln, \\ Nebraska68588-0118; email: dpilson1@unl.edu,hrp@unlserve.unl.edu
}

Key Words genetically engineered crop, GM crop

- Abstract Ecological risks associated with the release of transgenic crops include nontarget effects of the crop and the escape of transgenes into wild populations. Nontarget effects can be of two sorts: $(a)$ unintended negative effects on species that do not reduce yield and $(b)$ greater persistence of the crop in feral populations. Conventional agricultural methods, such as herbicide and pesticide application, have large and welldocumented nontarget effects. To the extent that transgenes have more specific target effects, transgenic crops may have fewer nontarget effects. The escape of transgenes into wild populations, via hybridization and introgression, could lead to increased weediness or to the invasion of new habitats by the wild population. In addition, native species with which the wild plant interacts (including herbivores, pathogens, and other plant species in the community) could be negatively affected by "transgenic-wild" plants. Conventional crop alleles have facilitated the evolution of increased weediness in several wild populations. Thus, some transgenes that allow plants to tolerate biotic and abiotic stress (e.g., insect resistance, drought tolerance) could have similar effects.

\section{INTRODUCTION}

Tomato with delayed ripening and canola with altered oil content were, in 1994, the first commercially released transgenic crops in the United States. In the past ten years, the number of hectares planted with crops containing genetic material derived from unrelated species has increased dramatically. Worldwide in 2003 transgenic crops were planted on more than 67.7 million hectares (James 2003). The United States accounted for $63 \%$ of this total, growing transgenic crops on 42.8 million hectares. Other large producers are Argentina, Canada, Brazil, China, and South Africa, and together with the United States, these countries plant about $99 \%$ of all transgenic crops worldwide. In the United States in 2003, $40 \%$ of the corn, $81 \%$ of the soybeans, and $73 \%$ of the cotton was transgenic, and these crops together account for the vast majority of transgenic plantings. Other transgenic 
crops planted in the United States in 2003 include canola, squash, and papaya (James 2003).

Although more than 40 crop phenotypes have been approved for commercial release in the United States (ISB 2004a), herbicide tolerance (in soybean, cotton, corn, and canola) and insect resistance [conferred by toxin genes derived from Bacillus thuringiensis (Bt) in cotton and corn] account for nearly all the transgenic hectareage in this country (James 2003). Transgenic virus-resistant squash and papaya are also currently planted, but together they are planted on only a few thousand hectares (although more than half of U.S. papaya crop consists of transgenic varieties) (Gianessi et al. 2002). Other crops that have been approved for commercial sale, but that have been withdrawn from the market or are rarely adopted by farmers, include $B t$ potatoes, $B t$ and herbicide-tolerant sweet corn, herbicide-tolerant sugar beets, canola with altered seed oil content, and tomatoes with various quality traits.

Three types of potential risks are associated with the commercial release of transgenic crops: food safety, agronomic, and ecological. Food safety risks include, for example, the potential for allergenicity and decreased food quality of transgenic crops relative to their nontransgenic progenitors. Food safety issues have been reviewed by Kaeppler (2000), the Royal Society (2002), GM Science Review Panel (2003, 2004), Kok \& Kuiper (2003), and Thomson (2003). Agronomic risks include crop-to-crop gene flow and the evolution of insecticide resistance in insect pests and herbicide resistance in weeds. These issues have been reviewed by Tabashnik (1994), Gould (1998), Shelton et al. (2000), Tabashnik et al. (2003), Martinez-Ghersa et al. (2003), and Mellon \& Rissler (2004). The focus of this review is the potential for ecological risks resulting from the commercial release of transgenic crops. Over the past several years, ecological risks have been discussed at considerable length in the literature [Tiedje et al. 1989; Rissler \& Mellon 1996; Snow \& Moran-Palma 1997; Wolfenbarger \& Phifer 2000; Dale et al. 2002; Letourneau \& Burrows 2002; National Resource Council (NRC) 2000, 2002a; GM Science Review Panel 2003, 2004; Snow et al. 2004]. Also, many websites provide a wealth of information on transgenic crops. A particularly useful site is maintained by Information Systems for Biotechnology (ISB) at Virginia Tech University (www.isb.vt.edu); links to other sites can be found at the ISB site.

Ecological risks can be divided into two types. First, nontarget effects of transgenic crops occur when the expression of a transgene in a crop has negative effects on nontarget species. For example, corn engineered to express a $B t$ toxin gene will have intended negative effects on lepidopteran pests, but it may also have unintended direct or indirect effects on native nonpest species. Nontarget effects could also occur if the crop becomes more persistent in nonagricultural habitats. Second, transgenes might escape into wild populations through the hybridization of crop plants with their wild relatives. Transgenes that increase to high frequency in wild populations might affect seed production, population size, or habitat use in the wild species. In addition, transgenes for insect resistance that establish in wild populations could have negative effects on native herbivores as well as on 
species with which the native herbivores interact. Horizontal gene transfer, via recombination, from transgenic plants to viruses or bacteria is also possible.

\section{NONTARGET EFFECTS OF GENETICALLY MODIFIED CROPS}

The many hypothesized nontarget effects of transgenic crops fall into two general categories. First, nontarget species could be affected, either directly or indirectly, by the transgenic product. For example, the abundance of nonpest herbivores, predators and parasitoids of target species, or pollinators might be reduced on transgenic crops. Similarly, the soil microbial community might be altered under transgenic plants. Second, a transgene that alters the habitat requirements of a crop plant could allow cultivation of crops or persistence of feral plants in previously unsuitable habitats. This could lead to a reduction in the quantity or quality of native habitat.

\section{Species Effects of Transgenic Crops}

DIRECT EFFECTS ON NONTARGET HERBIVORES Researchers estimate that insect herbivory reduces crop yields by $30-40 \%$ worldwide (Oerke et al. 1994). In response, insecticides, traditionally bred insect resistance, and now transgenic resistance are used to reduce yield losses. Each of these management tools may have unintended effects on nontarget species. For example, effects of insecticides have been well documented (Benbrook 1996). By contrast, little work has evaluated nontarget effects of traditionally bred resistance. To the extent that transgenic resistance is specific to a particular group of pests (e.g., Bts), effects on nontarget herbivores of transgenic crops might be less common.

A direct effect on nontarget species occurs when the transgenic trait in the crop negatively affects herbivores that do not reduce crop yield. These nontarget species generally feed on the crop, but they may also feed on plants in and adjacent to the crop field. Several studies have examined the direct effects of transgenic plants or artificial diet with transgenic protein on nontarget herbivores (see Poppy 2000 for review), although it is not clear that all these species would naturally feed on transgenic crops (see Supplemental Table 1 and nontarget entries in Supplemental Table 3: Follow the Supplemental Material link from the Annual Reviews home page at http://www.annualreviews.org). Most of these experiments evaluated the effect of a $B t$ toxin on a nonlepidopteran herbivore, and most studies found no effect. Just four studies evaluated the effects of transgenes other than $B t$, and in all four a negative effect was found. Without knowing more about patterns of host use in these nontarget herbivores or about the effects of conventional management practices on nontarget species, it is difficult to evaluate the ecological importance of these results.

Less commonly, a transgenic plant could directly affect herbivores feeding on adjacent plants. Perhaps the best-known example is the case of $B t$ corn pollen 
and the monarch butterfly. Losey et al. (1999) reported that monarch larvae fed milkweed leaves dusted with $B t$ corn pollen in the laboratory had decreased survival. The logical conclusion of this work was that if milkweed plants adjacent to $B t$ corn frequently accumulate large amounts of $B t$ pollen, and if such plants constitute a large proportion of the milkweed available to monarchs, then monarch populations would be negatively affected. Since the original Losey et al. (1999) study, and an additional study by Jesse \& Obrycki (2000), a huge effort has been made to evaluate the risk to monarchs presented by $B t$ corn. In particular, a research consortium funded by the U.S. Department of Agriculture (USDA) and an industry group completed several studies on different aspects of the monarch-milkweed$B t$-corn interaction and found the risk to be negligible (Sears et al. 2001, Wraight et al. 2000, Hellmich et al. 2001, Oberhauser et al. 2001, Pleasants et al. 2001, Stanley-Horn et al. 2001). Although high concentrations of Bt corn pollen clearly have negative effects on monarch larvae, only a very small proportion of milkweed plants accumulate any $B t$ pollen, let alone pollen in sufficient concentration to have negative effects (see Obrycki et al. 2001 for review). Few other cases of potential nontarget effects on adjacent plants have been examined (Wraight et al. 2000, Zangerl et al. 2001).

EFFECTS ON POLLINATORS The effect of transgenic pollen on foraging, learning, and life history characteristics of honeybees and bumblebees has been evaluated in several laboratory studies (Supplemental Table 2). The general conclusion from this work is that proteinase inhibitors have negative effects on bees, but that $B t$ does not (Supplemental Table 2; and for review, Malone \& Pham-Delegue 2001). However, interpretation of these results is difficult because the concentrations of transgenic product used in these laboratory tests, often with artificial diet, may be greater than typically encountered in the field, and the importance of nontransgenic varieties and other species in the diet is unknown.

EFFECTS ON THE THIRD TROPHIC LEVEL Natural enemies of crop pests can greatly affect pest abundance and are often used in integrated pest management programs (Bellows \& Hassell 1999). Conversely, broad-spectrum insecticides generally reduce natural enemy abundance (Croft 1990). Thus, a potential advantage of transgenic crops is that relatively specific resistance to particular insect pests might leave natural enemies unaffected. However, Groot \& Dicke (2002) argue that little is known about how changes in herbivore abundance or quality might affect the food web.

A variety of studies have evaluated effects of transgenic crops on the natural enemies of crop-feeding herbivores (Supplemental Table 3; see also Schuler et al. 1999 for review). In these studies, all combinations of effects have been found. The prey species can be either affected or unaffected by eating the transgenic product. In turn, predators can be either affected or unaffected by eating prey that have eaten transgenic product. It appears that effects on the predator (thirdtrophic-level effects) are most likely when the prey species is affected by eating the transgenic crop (or transgenic product in an artificial diet). This result contrasts 
with the suggestion by Groot \& Dicke (2002) that unaffected prey may not modify the transgenic product, which retains its toxicity to the predator. Thus, although direct toxicity is sometimes observed (e.g., Hilbeck et al. 1998), this effect may be uncommon.

In addition to effects of the transgenic product or prey quality on predator performance, reductions in prey abundance may also lead to a reduction in predator abundance in transgenic fields. For example, a specialist predator of Colorado potato beetle was less abundant in transgenic potato fields, presumably because its prey was also less abundant (Riddick et al. 1998). By contrast, the abundance of a generalist predator (that feeds on herbivores not targeted by $B t$ potato, as well as on Colorado potato beetle) was not affected by transgenic potato (Riddick et al. 1998). Similarly, in other field studies (Hoffmann et al. 1992, Pilcher et al. 1997, Orr \& Landis 1997), the densities of predators were generally not reduced in transgenic fields.

EFFECTS ON THE SOIL COMMUNITY: MICROORGANISMS AND MACROFAUNA The composition and activity of the soil microbial community are profoundly affected by the plant community (through both root exudates and litter quality and quantity), as well as by characteristics of the soil, climate, and, in agricultural communities, management practices. For example, plant species, and even crop variety, can have very large effects on rhizosphere microbial communities (Kourtev et al. 2003; Wardle 2002, Chapter 3). It is against this backdrop of natural variation that researchers must evaluate the potential effect of transgenic crop varieties. Studies of the effects of transgenic crops on the soil microbial community are summarized in Supplemental Table 4. Kowalchuk et al. (2003) have reviewed these effects and conclude that changes induced by transgenic plants are generally small relative to the effects of plant community and ecosystem properties. Similarly, transgenic varieties generally do not have negative effects on soil macrofauna (Supplemental Table 5).

Transgenic crops could affect the soil community in one of two ways. First, transgenic products could exude from roots and directly affect soil organisms; this possibility has been evaluated in a number of studies (e.g., Saxena et al. 1999, Saxena \& Stotsky 2001). Second, transgenic crops could affect plant tissue quality (e.g., lignin or cellulose content) (Escher et al. 2000; Hopkins et al. 2001; for review, see Halpin \& Boerjan 2003) and therefore affect tissue decomposition rates. Effects on tissue quality are most likely to have important ecological consequences (Kowalchuk et al. 2003). However, because links between microbial community structure and functional consequences (such as $\mathrm{C}$ and $\mathrm{N}$ cycling) are only poorly understood (Wardle 2002), these effects are difficult to evaluate.

\section{Habitat Effects of Transgenic Crops}

TRANSGENIC CROPS MAY BECOME FERAL If a cultivar contains a transgene that enhances the fitness of crop plants in weedy environments, the crop might become 
feral or might persist longer in feral populations. The potential for increased weediness in feral crops has been discussed widely (Snow \& Moran-Palma 1997, Rissler \& Mellon 1996, Warwick et al. 1999, Marvier 2001) but has received relatively little empirical attention. Parker \& Kareiva (1996) and Bullock (1999) advocate the use of population matrix models to evaluate this risk. This approach involves gathering demographic data on nontransgenic varieties of crops in appropriate habitats (such as fields and roadsides), using these data to construct projection matrices, then performing elasticity analyses to determine which demographic transitions have the largest effects on $\lambda$, the annual rate of population increase. By comparing the transitions affected by particular transgenes with the transitions important for population growth, the potential weediness of a transgenic variety can be evaluated.

Few studies have taken such an explicitly demographic approach to evaluate the potential for transgenic crops to persist in feral populations. Parker \& Kareiva (1996) found that transgenic oil-modified canola varieties had $\lambda$ 's that were not significantly different from those of nontransgenic isolines. Crawley et al. (1993, 2001) found no differences in persistence between transgenic herbicide-tolerant and nontransgenic varieties of oilseed rape, maize, beet, or potato. However, because the varieties used in Crawley et al.'s experiments were herbicide tolerant, and persistence was evaluated in the absence of herbicide, these results are not especially informative. It seems more likely that resistance to insects, pathogens, or other environmental stresses will enhance persistence in feral populations. For example, oilseed rape persists on road verges in France (Pessel et al. 2001), and time to extinction of feral populations might increase if plants contained transgenic insect resistance or drought tolerance.

REDUCTION IN WEED OR PEST POPULATIONS MAY NEGATIVELY AFFECT SPECIES USING AGRICULTURAL HABITATS Crop yields can be substantially reduced by insects, other pests, and weeds. To maintain yield, farmers spray herbicides and pesticides, cultivate fields, alter planting times, and plant conventionally bred varieties that are resistant to pests or are tolerant of herbicides. This intensification of farm management practices has led to a reduction in farmland biodiversity, including reductions in weed, invertebrate, and bird populations (reviewed in Champion et al. 2003). Transgenic crops represent a further intensification of agriculture, and the effects of this technology on remaining farmland biodiversity are of some concern. For example, Watkinson et al. (2000) modeled the effect of herbicide-resistant transgenic sugar beet on weed biodiversity and bird populations using farmland in Great Britain. Depending on the particular management practices considered, their model predicts large decreases in weed biodiversity. Because insects feed on these weeds, and some farmland birds depend on these insects, decreased weed biodiversity and abundance results in decreased bird populations.

In response to this concern, the Farm Scale Evaluations (FSE) were initiated in Great Britain in 2000. These studies involve transgenic and conventional varieties of four crops, each planted in a split-field design at 60-70 sites across Great 
Britain (Firbank et al. 2003, Squire et al. 2003, Champion et al. 2003). The transgenic crops included in this study are glyphosate-resistant sugar beet, glufosinateresistant field corn, and glufosinate-resistant spring- and winter-sown oilseed rape (canola); results for winter-sown rape are not yet published. Dicot and monocot weed populations, including seedbank populations (Heard et al. 2003a,b); aboveand below-ground invertebrate biodiversity, including pollinators (Brooks et al. 2003, Haughton et al. 2003); and higher-trophic-level effects (Hawes et al. 2003) were monitored over the following three years in the fields and at field margins (Roy et al. 2003). The larger objective of this work is to determine if genetically modified crops (and the management practices associated with these crops) affect farmland biodiversity differently than the management practices associated with conventional agriculture.

Data presented in papers published in 2003 (cited in the previous paragraph) suggest that transgenic varieties of sugar beet and spring-sown oilseed rape have reduced above- and below-ground (seedbank) populations of weeds, and reduced weed populations have led to generally reduced insect populations. In contrast, transgenic corn had higher weed and weed seedbank densities and generally higher insect populations than did the conventional corn fields. This is presumably because atrazine, the conventional herbicide used in corn, was more effective than glufosinate. A detailed interpretation of the FSE results and an in-depth review of other studies examining effects of transgenic herbicide-resistant crops is found in Squire et al. (2003), and Andow (2003) provides a succinct graphical summary of the results published to date. Similarly, in a comparison of transgenic and conventional soybeans, Buckelew et al. (2000) reported that weed management systems that allowed more weeds to persist supported larger insect populations.

The FSE results have been interpreted by some as evidence that transgenic herbicide-resistant beet and oilseed rape are bad for the environment, whereas transgenic herbicide-resistant maize is good for the environment (for discussion, see Dewar et al. 2004). However, another interpretation might be that transgenic varieties with improved weed control will allow higher yields and thus permit the return of marginal agricultural land to natural vegetation. In addition, application of generally less toxic herbicides (e.g., glyphosate) may be environmentally beneficial. Thus, the negative effects of transgenic crops on farmland biodiversity must be weighed against the potential benefits associated with increased yield and decreased herbicide use.

ADDITIONAL LAND MAY BE PLACED IN CULTIVATION Transgenes that affect agronomic properties (e.g., salt tolerance, Zhang et al. 2001; water stress, Hsieh et al. 2002; low soil iron availability, Takahashi et al. 2001) could allow cultivation of currently marginal land that is nonetheless good native habitat. Conversely, through irrigation farmland often becomes too saline to sustain economically viable crops (Ghassemi et al. 1995), and transgenic salt tolerance could allow this land to remain in cultivation. These effects are currently hypothetical and have received little consideration. 


\section{MECHANISMS AND RISK OF ESCAPE OF TRANSGENES INTO WILD POPULATIONS}

There are two mechanisms through which transgenes could move into wild populations: horizontal gene transfer and hybridization. Each of these mechanisms is discussed below.

\section{Horizontal Gene Transfer}

VIRUSES Transgenic virus resistance in crops released thus far has been achieved by insertion of a viral coat protein, and there is concern that recombination between infecting viruses and the transgene could result in new virus genotypes with altered host range, transmissibility, or virulence. Accumulating evidence suggests that virus/transgene recombination is likely, although most (but not all; see Aaziz \& Tepfer 1999) studies have been done in laboratory conditions favoring recombination (for review, see Hammond et al. 1999, Rubio et al. 1999, Power 2002, Tepfer 2002). As discussed by Hammond et al. (1999), the ecological risks of such recombination must be evaluated against the effects of natural recombination between viruses in mixed infections, which presumably occurs at similar rates. Because such recombination can have large effects on the population biology of viruses, and in fact is responsible for much viral evolution (Roossinck 1997), the potential ecological consequences (e.g., on the effects of virus infection in wild plants) deserve further attention (Tepfer 2002, Power 2002).

Another risk associated with virus coat proteins in transgenic crops is the possibility that viral RNA will be encapsidated with transgenic coat protein. Transencapsidation is known to occur in natural mixed infections, and it can alter the transmissibility of a virus. However, because the viral genome is unaltered, this effect does not persist, and for this reason ecological risks associated with transencapsidation are thought to be low (Hammond et al. 1999). Finally, increased disease severity may occur if there are synergistic interactions between invading viruses, and by extension, potentially between invading viruses and transgenic viral genes (Tepfer 2002, Power 2002).

SOIL BACTERIA Horizontal gene transfer could also occur by natural transformation, a process through which DNA that is free in the environment can be stably integrated into the genome of competent bacteria (Nielsen et al. 1998, Bertolla \& Simonet 1999). Although natural transformation is probably rare in nature (Nielsen et al. 1998, Gebhard \& Smalla 1999, Nielsen et al. 2001), it is generally observed at low frequency in favorable experimental conditions (Schlüter et al. 1995; Nielsen et al. 1997, 2000a,b; Kay et al. 2002).

\section{Hybridization with Wild Relatives}

The ecological risks associated with the movement of transgenes into wild populations via hybridization must be evaluated by sequentially addressing three 
questions: (a) Is the transgenic variety of the cultivated plant sexually compatible with wild relatives? If the crop has no compatible wild relatives, then no crop genes can move into wild populations, and there is no risk of transgene escape. However, if the crop does have compatible relatives, the next question is, (b) Will the transgene increase in frequency in the wild population (either by demographic swamping or by natural selection)? If the transgene is not expected to increase in frequency, then the ecological risks of transgene escape are minimal. Finally, if the transgene increases the fitness of the wild relative, and therefore the transgene is expected to increase in frequency in wild populations by natural selection, the third question is, $(c)$ What are the ecological consequences of the escape of the transgene into a wild population? We address the first two questions in the next two sections. In the Consequences of the Escape of Transgenes into Wild Populations section below, we discuss the third question.

IS THE TRANSGENIC VARIETY OF THE CULTIVATED PLANT SEXUALLY COMPATIBLE WITH WILD RELATIVES? All crop species were derived from one (or more) wild species, and most crops are planted sympatrically with compatible wild relatives somewhere in the world (Ellstrand 2003, Ellstrand et al. 1999). In addition, although the fertility of F1 crop-wild hybrids varies dramatically, both among crops and among crosses within crops, frequently fertility is restored in F2, BC1, and later generations. For example, in sunflower, F1 crop-wild hybrids have fertilities ranging from $1 \%$ to $100 \%$ of wild fertility, depending on the cross (Snow et al. 1998, Cummings et al. 2002), and the frequency of cultivar-specific alleles drops in later generations (Cummings et al. 2002). However, several studies have demonstrated that cultivar alleles persist in wild and weedy sunflower populations (Arias \& Rieseberg 1994, Linder et al. 1998, Whitton et al. 1997). In fact, hybridization with wild relatives has been documented for 22 of the 25 most important crop species (by worldwide area planted) (Ellstrand 2003, and see Eastham \& Sweet 2002), and it is likely that crop genes have introgressed into these wild populations. In addition to the overwhelming empirical evidence of gene flow between crops and their wild relatives (e.g., Warwick et al. 2003), theoretical models also suggest that introgression of transgenes is likely (e.g., Meagher et al. 2003, Thompson et al. 2003).

Because it is generally expected that crops will hybridize with their wild relatives, a variety of genetic methods of reducing the probability of introgression are under consideration and development (reviewed in Daniell 2002, NRC 2004). These include placing transgenes on chromosomes or chromosome segments that are less likely to introgress into wild populations (e.g., Rieseberg et al. 1999, 2000), closely linking transgenes with genes for domestication traits that are expected to have low fitness in wild populations, and controlling the viability or fertility of hybrid offspring using gene use-restriction technology.

Another way to reduce the risk of crop-wild hybridization is to restrict transgenic crops to areas where wild relatives do not occur. For example, wild relatives of corn and soybeans are not native to the United States, and thus, in this country, 
transgenes from these crops cannot move into wild relatives. Similarly, in the United States transgenic cotton is restricted to areas where wild relatives of cotton do not grow naturally (Mendelsohn et al. 2003). By contrast, transgenic virusresistant squash (Cucurbito pepo) is planted within the native range of wild squash, also Cucurbito pepo (Wilson 1993). Although cultivated alleles have been found in wild populations (Kirkpatrick \& Wilson 1988, Decker-Walters et al. 2002), little is known about either the importance of viruses in wild populations (Spencer \& Snow 2001) or the frequency of hybridization between cultivated and wild squash.

Because humans move seeds around the globe, both intentionally and accidentally, restricting transgenic crops to areas outside the native range will only temporarily delay the movement of transgenes into wild relatives. For example, even though cultivation of transgenic corn has been prohibited in Mexico since 1998, transgenic material has been found in land races of maize in remote mountainous regions of Oaxaca (Quist \& Chapela 2001, 2002; and see Biotech InfoNet 2002, Mann 2002). The ecological effect of a Bt gene that introgresses into the land races will clearly depend on the importance of lepidopteran herbivores in these populations, which is unknown. If pleiotropic effects of the $B t$ gene are weak or absent, and if linkage to other cultivar-derived traits is reduced by recombination, the $B t$ gene will only increase in frequency in the land races if it leads to the reduction of lepidopteran damage and, therefore, to an increase in seed production. Moreover, even if selection favoring the $B t$ gene in land races is strong, genetic diversity in the land races will be reduced only at loci tightly linked to the $B t$ gene itself (Maynard Smith \& Haigh 1974). Thus, overall genetic diversity in the land races (and in other wild populations into which transgenes introgress) is unlikely to be affected by the escape of transgenes. In fact, at least initially, genetic diversity in wild populations hybridizing with crops may be increased (Ellstrand 2003, table 9.1).

WILL THE TRANSGENE INCREASE IN FREQUENCY IN THE WILD POPULATION? In contrast to the huge literature evaluating the potential for hybridization between transgenic crops and their wild relatives, there are few studies that have attempted to evaluate the fitness effects of transgenes once they have entered wild populations (Letourneau et al. 2003). Moreover, many authors seem to assume that if hybridization is rare (or can be made less common by the use of appropriate genetic technologies), then the consequences of hybridization do not need to be considered (e.g., Stewart et al. 2003). Similarly, many authors have suggested that if crop-wild hybrids have low fitness, the probability of introgression of a transgene into the wild population is low. This assertion is contradicted by theoretical work (Barton 1986) indicating that the rate of introgression of an allele from one population to another through hybrids can be very rapid even if the selective advantage is small, as well as by the frequent occurrence of transgressive hybrids (Rieseberg et al. 2003). In addition, Rieseberg \& Wendel (1993) have documented the importance of introgression in the evolution of plant populations. Thus, evaluating the conditions under which transgenes will increase in frequency in wild populations is crucial. 
A transgene could increase in frequency by either demographic swamping or by natural selection. Demographic swamping occurs with continual migration from a large source population (e.g., a crop) into a smaller recipient population (e.g., a wild relative). In a theoretical model, Haygood et al. (2003) found that with continual migration, as would occur when the crop is continuously planted, crop alleles can rapidly become fixed in wild populations, even when they are deleterious. In particular, alleles that reduce fitness can be fixed if the migration rate exceeds the selection coefficient, and when this occurs demographic swamping can lead to reduced population size and possibly local extinction. These effects (see also Huxel 1999, Wolf et al. 2001, Ferdy \& Austerlitz 2002) could lead to extinction by hybridization (e.g., Levin et al. 1996, Rhymer \& Simberloff 1996) and to wild populations that are endangered because of hybridization with crops (Ellstrand 2003, table 9.4).

If, instead, the effects of natural selection are expected to be more important than the effects of migration, then we must evaluate the fitness effects of the transgene in wild plants. The appropriate way to evaluate these effects is to compare the fitness of transgenic plants with the fitness of plants of the same genetic background but without the transgene. From this sort of experiment it is possible to estimate $s$, the selection coefficient, which quantifies the strength of selection either favoring or not favoring genotypes that include the transgene (Hartl \& Clark 1997). Statistically significant selection favoring transgenic plants implies that the transgene will increase in frequency in wild populations. Moreover, if the phenotype of transgenic plants is the phenotype predicted by the transgene (e.g., lepidopteran resistance in the case of a $B t$ gene), then increased (or decreased) fitness of transgenic plants can more confidently be ascribed to the transgene, rather than to an idiosyncratic position effect. Ideally, these experiments should be done in more than one environment and year, so that the results can be more easily generalized. In addition, if the benefit of the transgene is predicted to vary across environments (e.g., because the environments vary in herbivore pressure) then the strength of selection favoring the transgene should vary as well.

If the transgene is of no benefit (or is always costly) to the wild plant, genetic drift (or purifying selection) will determine its fate in the wild population. For example, transgenes controlling traits such as ease of harvest, fruit ripening, and product shelf life, as well as newer generation traits such as pharmaceutical or industrial chemical production, are likely to be neutral or costly in wild populations. Similarly, although weeds with transgenic herbicide resistance may be more difficult to control with herbicides, these genes are likely to be neutral or costly in wild populations that are not sprayed (Snow et al. 1999, Gueritaine et al. 2002, Zhang et al. 2003).

In contrast to costly or neutral characters, transgenes for characters such as insect or pathogen resistance and drought tolerance may benefit wild populations, and therefore may increase in frequency in wild populations by natural selection. For example, damage by herbivores is generally detrimental to plant fitness in wild populations (e.g., Marquis 1992, Crawley 1997, Letourneau et al. 2002), and similarly viruses and fungal pathogens also commonly reduce fitness of wild plants 
(e.g., Burdon 1987, Jarosz \& Davelos 1995, Maskell et al. 1999). These results suggest that transgenic herbivore and pathogen resistance would be favored by natural selection in many wild relatives of crop plants. The evolutionary dynamics of each of these traits will be determined by the balance between the benefit of the trait (in the presence of the selective agent, such as herbivores) and the cost of the trait (the reduction in fitness of transgenic individuals in the absence of the selective agent) (Simms \& Rausher 1987).

Only one study has evaluated the fitness effects of a transgene in a wild genetic background in an ecologically relevant environment. In field-planted BC1 and BC3 Helianthus annuus with a Bt transgene, lepidopteran damage was reduced to near zero, and seed production was increased $15-55 \%$ (relative to plants without the transgene), depending on the year and field site (Snow et al. 2003, Pilson et al. 2004). Because lepidopteran damage is known to reduce fitness in wild Helianthus annuus populations (Pilson 2000, Pilson \& Decker 2002), this result is not surprising. Moreover, when BC1 plants were grown in the greenhouse (in the absence of herbivores), there was neither a benefit nor a cost of the transgene (Snow et al. 2003). These results suggest that, if a Bt gene were to escape into wild sunflower populations, it would increase in frequency by natural selection, and the rate of increase would vary in space and time as a function of the abundance of lepidopteran herbivores.

A few additional studies have evaluated effects of transgenes in F1 or BC plants. In a cage experiment replicated in three states in the United States, Burke \& Rieseberg (2003) experimentally inoculated BC3 sunflower segregating for a transgene conferring resistance to white mold. They found that both the effect of the transgene on infection frequency and the effect of infection on seed production depended on the location of the experiment. Furthermore, because the transgene had no effect on infection in locations where the pathogen had large effects on fitness, in this experiment the transgene provided no fitness benefit. Fuchs \& Gonsalves (1997, 1999) found that transgenic virus-resistant F1 and BC1 squash inoculated with virus do not display symptoms and do produce fruit. $\mathrm{BC} 1$ and $\mathrm{BC} 2$ Brassica rapa plants (with a $B t$ gene introgressed from Brassica napus) produced more reproductive biomass than nontransgenic plants when inoculated with high, but not low, densities of diamondback moth larvae (Mason et al. 2003). Furthermore, in the absence of moth larvae there was no effect of the $B t$ gene on plant growth, indicating that the $B t$ gene is not costly to the plant (Mason et al. 2003). However, interpreting these studies is difficult because the incidences of naturally occurring white mold in wild sunflower populations, virus in wild squash populations, and diamondback moth in weedy $B$. rapa populations are not reported.

Because it is known that conventionally bred crop alleles have introgressed into wild populations, one way to evaluate the potential effects of transgenes in these populations is by examining the effects of these conventional alleles. Ellstrand (2003) documents 16 cases in which crop-wild hybridization has led either to the evolution of a new taxon (Ellstrand 2003, table 9.2) or to a wild population with changed ecological properties (Ellstrand 2003, table 9.3). In most of these cases 
the newly derived taxon or population is weedier than its wild parent. Clearly, crop alleles can sometimes enhance weediness in wild plants, but whether transgenes are more likely than conventional alleles to have this effect is an open question. Genes that affect environmental tolerances (e.g., resistance to biotic and abiotic stress) would seem the most likely candidates.

Genetic and ecological models provide another way to evaluate the potential effects of transgene movement into wild populations. Muir \& Howard (1999, 2001, 2002; Howard et al. 2004) have developed and parameterized a model for transgenic fish that is now being modified for application to plant populations (ISB 2004b). Their original model predicts that a transgene that increases growth rate and adult size can (paradoxically) cause the extinction of wild populations. Extinction occurs because the transgene has opposite effects on different components of fitness, and this phenomenon has been called the Trojan gene hypothesis. Specifically, larger fish (with the transgene) get most of the matings, but because their transgenic offspring have lower viability, few survive to maturity, and population size declines. Evaluating the effects of a transgene on various components of fitness in plant populations is clearly of value (e.g., to measure $\lambda$; see Parker \& Kareiva 1996, Bullock 1999). However, for plants it is not clear how frequently transgenes might have such different effects on mating success and offspring viability.

\section{CONSEQUENCES OF THE ESCAPE OF TRANSGENES INTO WILD POPULATIONS}

Although the movement of a transgene into a wild population, and its subsequent increase in frequency, are necessary, they are not sufficient to predict the environmental consequences of transgene escape. Specifically, these processes are only important to the extent that they lead to the alteration of existing ecological interactions between the wild plant and its biotic and abiotic environment. Thus, it is necessary to answer the third question raised above: What are the ecological consequences of the escape of the transgene into a wild population? A transgene that increases in frequency by natural selection in a wild population does so, by definition, because it increases survival or fecundity, and one ecological risk is the effect of increased individual fitness on population size, dynamics, and habitat use in the wild plant. In addition, transgenes that confer resistance to herbivores and pathogens will have direct effects on native species using the wild plant as a host. Clearly, these questions must be the crux of any ecological risk assessment. However, very little work has been done in these areas.

\section{Population Dynamics and Habitat Use in the Wild Relative}

A much discussed potential consequence of the escape of transgenes into wild populations is that transgenic-wild plants will become weedier (Darmency 1994, Snow \& Moran-Palma 1997, Warwick et al. 1999). The size of transgenic-wild 
populations could increase in the wild plant's original habitat, or broader environmental tolerances could allow transgenic-wild plants to invade previously unsuitable habitat. These risks are difficult to evaluate because little is known about factors controlling population size or range in plants, or about characteristics of invading species and the receiving community that allow invasion (Hoffmann \& Blows 1994, Lonsdale 1999, Kolar \& Lodge 2001, Gerlach \& Rice 2003).

INCREASE IN POPULATION SIZE A transgenic-wild population could increase in size if either fecundity (e.g., Snow et al. 2003) or competitive ability (e.g., Damgaard \& Jenson 2002) increase as a result of expressing the transgene, and if population size was previously limited by characters affected by the transgene. However, this possibility is difficult to evaluate because little is known about factors controlling population size in natural plant populations. However, changes in fecundity can have large effects on population growth rate ( $\lambda$; Silvertown et al. 1993), suggesting that transgenes that increase fecundity could lead to increases in population size. Fecundity in sunflowers is limited by herbivory (Pilson 2000), and experimental sunflower populations in western Nebraska appear to be seed-limited, suggesting that a reduction in herbivory would lead to larger populations. In contrast, in similar populations in eastern Kansas population size is affected more by densitydependent processes (such as competition for resources) than by seed production (D. Pilson, H. Alexander, J. Moody-Weis, A. Snow, manuscript in preparation). Seed production by individual thistle plants and thistle populations can be limited by insect herbivory (Louda \& Potvin 1995, Guretzky \& Louda 1997). Weedy roadway populations of oilseed rape were seed-limited at the landscape scale (Crawley \& Brown 1995). Small experimental populations of Arabidopsis thaliana were not seed-limited (Bergelson 1994).

Within a community, a likely consequence of an increase in population size of one species is the decrease in size of others. For example, in experimental plots in which goldenrod plants were sprayed with insecticide, goldenrod abundance increased while the abundance of other species decreased (Carson \& Root 1999, 2000). This effect was attributed to increased competitive ability when plants were not subject to insect attack. These results suggest that if insect-resistant transgenic-wild plants (or plants with any character that increases competitive ability) are present, the abundance of other species could decline. Changes in community structure in natural habitats are thus one potential consequence of the incorporation of transgenes into wild populations.

INVASION OF PREVIOUSLY UNSUITABLE HABITAT In addition to increased population size in their original habitat, transgenic-wild plants might also be able to invade previously unsuitable habitats. For example, one reason introduced plants are believed to become invasive is that they have escaped from their natural enemies (Mack et al. 2000, Sakai et al. 2001, NRC 2002b, Louda et al. 2003, Mitchell $\&$ Power 2003, Callaway et al. 2004). Escape from natural enemies might allow invasion directly, or reduced natural enemy attack might free resources and thus allow the evolution of increased competitive ability (Blossey \& Nötzold 1995; but 
see Willis et al. 1999, 2000). In addition, hybridization has been shown to provide the genetic variation necessary for the evolution of invasiveness in many taxa (Ellstrand \& Schierenbeck 2000), and transgressive segregation is common in crop and wild populations (Rieseberg et al. 2003). Taken together these considerations suggest that crop-wild hybrids could facilitate the evolution of broader habitat tolerances, and perhaps invasiveness, in wild populations.

\section{Insect and Pathogen Community Structure}

If transgenes for resistance to herbivores or pathogens increase to high frequency in wild populations, there will be immediate, and negative, effects on those native species that were responsible for selection to increase the frequency of the transgene in the first place. If these species are specialists, their populations could decline dramatically, perhaps resulting in local extinction. By contrast, if these species have additional host plants, the effect of the transgene will depend on how important the transgenic-wild plant is in the diet of the herbivore or pathogen. For example, although many moths feed on more than one Helianthus sp., Helianthus аппии is the most important host for many lepidopteran herbivores (Charlet et al. 1992, 1997). This fact suggests that if a $B t$ gene were to enter wild $H$. annuus populations (Snow et al. 2003, Pilson et al. 2004), the abundance of $H$. annuus-feeding lepidopterans would decrease. Furthermore, because one of the most common moths feeding on $H$. annuиs has negative competitive effects on a seed midge and a seed weevil, reduction in lepidopteran abundance could result in increased seed midge and seed weevil populations (M. Paulsen \& D. Pilson, manuscript in preparation). Effects at the next trophic level might include increased abundance of seed midge and seed weevil parasitoids and decreased abundance of lepidopteran parasitoids. Community-level consequences of the removal of a few species are likely to be quite complex and unpredictable (Denno et al. 1995, Polis \& Strong 1996, Dunne et al. 2002, Groot \& Dicke 2002).

Changes in community structure that occur because of transgenic-wild plants will not be static. Specifically, transgenic herbivore or pathogen resistance will impose strong selection on the affected species to evolve counter-resistance, similar to the selection pressure imposed by conventional insecticides. Crop pests have evolved resistance to virtually all chemical insecticides applied to crops (NRC 1986), and thus there is every reason to expect that herbivores in natural systems will evolve resistance to transgenic pesticides. The speed with which this happens will depend on the strength of selection on the transgenic host, the presence of alternative hosts, and pre-existing variation for resistance.

\section{CURRENT TRANSGENES VERSUS TRANSGENES OF THE FUTURE}

Most of our discussion has focused on transgenic traits that are likely to enhance the fitness or environmental tolerances of wild plants (e.g., insect and pathogen resistance, drought tolerance), because these traits are most likely to affect natural 
plant and animal populations. Furthermore, much of our discussion of insect resistance has focused on $B t$ crops because these have been released commercially and extensively evaluated (Shelton et al. 2002, Mendelsohn 2003). In the future, crops with other types of insect resistance are likely (Schuler et al. 1999, Moar 2003), as are crops with transgenic resistance to pathogens and nematodes (Atkinson et al. 2003). The sorts of ecological risks discussed here will likely be relevant to these newer transgenic products as well. By contrast, the next generation of transgenic products will probably also include plants with enhanced product quality (e.g., increased yield, altered ripening time or nutritional content, reduced lignin content in trees), as well as plants producing industrial and pharmaceutical chemicals (Dunwell 1999, Fischer \& Emans 2000, Jaworski \& Cahoon 2003, Ma et al. 2003, Sinclair et al. 2004). Although some of these genes could present very large agronomic or food safety risks, they seem less likely to have important ecological effects. This is because these traits are less likely to increase the fitness of wild plants and so are less likely to increase in frequency in wild populations.

\section{POTENTIAL BENEFITS OF TRANSGENIC CROPS}

Although the focus of this review is the ecological risks associated with the commercial release of transgenic crops, it is important to recognize that there may be ecological benefits as well (Wolfenbarger \& Phifer 2000; Hails 2000). One potential benefit is a reduction in pesticide and herbicide use. For example, in the United States insecticide use has decreased on corn and cotton since the release of $B t$ varieties of these crops (Benbrook 2003). Similarly, in China planting Bt cotton has resulted in dramatic reductions in pesticide use (with both environmental and human health benefits) and increased yields (Pray et al. 2002). In addition, the use of $B t$ crops, rather than broad spectrum insecticides, could allow larger populations of beneficial insects and nonpest herbivores to persist in crop fields. However, herbicide use on herbicide-tolerant crops, especially soybean, has increased since the release of transgenic varieties, although this increase has largely been the result of increases in relatively benign herbicides such as glyphosate (Benbrook 2003). Another potential benefit of transgenic herbicide-tolerant crops is an increase in no-till or other conservation tillage practices, which lead to reduced soil erosion and run-off to streams, reduced fuel use (Fawcett \& Towery 2003), and increased sequestration of atmospheric carbon. Evaluating the ecological benefits of transgenic crops is not straightforward, and no comprehensive reviews have been published.

\section{CONCLUSIONS}

We draw three general conclusions. First, transgenes that affect plant response to biotic and abiotic stress (e.g., insect and pathogen attack, drought and salt tolerance) are more likely to have negative ecological effects than are transgenes 
for traits affecting product quality or industrial and pharmaceutical chemical production. Second, escape of transgenes into wild populations, via hybridization and introgression, is more likely to result in negative ecological effects than are nontarget effects of the transgenic crop itself. The escape of transgenes into wild populations could lead to increased weediness or the invasion of new habitats by the wild population. In addition, native species with which the wild plant interacts (including herbivores, pathogens, and other plant species in the community) could be negatively affected by transgenic-wild plants. Conventional crop alleles have allowed the evolution of increased weediness in several wild populations. Thus, there is reason to believe that some transgenes (e.g., for insect resistance, drought tolerance) could have similar effects. Finally, there are relatively few data available with which to evaluate the potential for increased weediness in wild relatives of crop plants. A better understanding of factors controlling population size, dynamics, and range limits in weedy plants is necessary before a full ecological risk assessment can be made.

\section{ACKNOWLEDGMENTS}

Kjärstin Carlson did a tremendous job locating references and organizing the reference list. Allison Snow commented on an earlier version of the manuscript. Discussions with Allison Snow and Helen Alexander have greatly influenced our perspective on ecological risks. Our work in this area has been supported by the USDA Biotechnology Risk Assessment Program.

\section{The Annual Review of Ecology, Evolution, and Systematics is online at http://ecolsys.annualreviews.org}

\section{LITERATURE CITED}

Aaziz R, Tepfer M. 1999. Recombination between genomic RNAs of two cucumoviruses under conditions of minimal selection pressure. Virology 263:282-89

Andow DA. 2003. UK farm-scale evaluations of transgenic herbicide-tolerant crops. Nat. Biotechnol. 21:1453-54

Arias DM, Rieseberg LH. 1994. Gene flow between cultivated and wild sunflowers. Theor. Appl. Genet. 89:655-60

Atkinson HJ, Urwin PE, McPherson MJ. 2003. Engineering plants for nematode resistance. Annu. Rev. Phytopathol. 41:615-39

Barton NH. 1986. The effects of linkage and density-dependent regulation on gene flow. Heredity 57:415-26
Bellows TS, Hassell MP. 1999. Theories and mechanisms of natural population regulation. In Handbook of Biological Control, ed. TS Bellows, TW Fisher, pp. 17-44. San Diego, CA: Academic

Benbrook CM. 1996. Pest Management at the Crossroads. Yonkers, NY: Consumers Union

Benbrook CM. 2003. Impacts of genetically engineered crops on pesticide use in the United States: the first eight years. http://www. biotech-info.net/Technical_Paper_6.pdf

Bergelson J. 1994. Changes in fecundity do not predict invasiveness: a model study of transgenic plants. Ecology 75:249-52

Bertolla F, Simonet P. 1999. Horizontal gene transfers in the environment: natural 
transformation as a putative process for gene transfers between transgenic plants and microorganisms. Res. Microbiol. 150:375-84

Biotech InfoNet. 2002. Bt corn gene flow in Mexico. http://www.biotechinfo.net/mexi can_bt_flow.html\#overview

Blossey B, Nötzold R. 1995. Evolution of increased competitive ability in invasive nonindigenous plants: a hypothesis. J. Ecol. 83: 887-89

Brooks DR, Bohan DA, Champion GT, Haughton AJ, Hawes C, et al. 2003. Invertebrate responses to the management of genetically modified herbicide-tolerant and conventional spring crops. I. Soil-surfaceactive invertebrates. Philos. Trans. R. Soc. London Ser. B 358:1847-62

Buckelew LD, Pedigo LP, Mero HM, Owen MDK, Tylka GL. 2000. Effects of weed management systems on canopy insects in herbicide-resistant soybeans. J. Econ. Entomol. 93:1437-43

Bullock JM. 1999. Using population matrix models to target GMO risk assessment. Aspects Appl. Biol. 53:205-12

Burdon JJ. 1987. Diseases and Plant Population Biology. New York: Cambridge Univ. Press. 208 pp.

Burke JM, Rieseberg LH. 2003. Fitness effects of transgenic disease resistance in sunflowers. Science 300:1250

Callaway RM, Thelen GC, Rodriguez A, Holben WE. 2004. Soil biota and exotic plant invasion. Nature 427:731-33

Carson WP, Root RB. 1999. Top-down effects of insect herbivores during early succession: influence on biomass and plant dominance. Oecologia 121:260-72

Carson WP, Root RB. 2000. Herbivory and plant species coexistence: community regulation by an outbreaking phytophagous insect. Ecol. Monogr. 70:73-99

Champion GT, May MJ, Bennett S, Brooks DR, Clark SJ, et al. 2003. Crop management and agronomic context of the Farm Scale Evaluations of genetically modified herbicidetolerant crops. Philos. Trans. R. Soc. London Ser. B 358:1801-18
Charlet LD, Brewer GJ, Beregovoy VH. 1992. Insect fauna of the heads and stems of native sunflowers (Asterales: Asteraceae) in eastern North Dakota. Environ. Entomol. 21:493500

Charlet LD, Brewer GJ, Franzmann BA. 1997. Sunflower insects. In Sunflower Technology and Production, ed. AA Schneiter, pp. 183261. Madison, WI: Soil Sci. Soc. Am.

Crawley MJ. 1997. Plant-herbivore dynamics. In Plant Ecology, ed. MJ Crawley, pp. 40174. Oxford, UK: Blackwell Sci.

Crawley MJ, Brown SL. 1995. Seed limitation and the dynamics of feral oilseed rape on the M25 motorway. Proc. R. Soc. London Ser. B 259:49-54

Crawley MJ, Brown SL, Hails RS, Kohn DD, Rees M. 2001. Transgenic crops in natural habitats. Nature 409:682-83

Crawley MJ, Hails RS, Rees M, Kohn D, Buxton J. 1993. Ecology of transgenic oilseed rape in natural habitats. Nature 363:620-23

Croft BA. 1990. Arthropod Biological Control Agents and Pesticides. New York: Wiley. 723 pp.

Cummings CL, Alexander HM, Snow AA, Rieseberg LH, Kim MJ, Culley TM. 2002. Fecundity selection in a sunflower crop-wild study: Can ecological data predict crop allele changes? Ecol. Appl. 12:1661-71

Dale PJ, Clarke B, Fontes EMG. 2002. Potential for the environmental impact of transgenic crops. Nat. Biotechnol. 20:567-74

Damgaard C, Jensen BD. 2002. Disease resistance in Arabidopsis thaliana increases the competitive ability and the predicted probability of long-term ecological success under disease pressure. Oikos 98:459-66

Daniell H. 2002. Molecular strategies for gene containment in transgenic crops. Nat. Biotechnol. 30:581-86

Darmency H. 1994. The impact of hybrids between genetically modified crop plants and their related species: introgression and weediness. Mol. Ecol. 3:37-40

Decker-Walters DS, Staub JE, Chung SM, Nakata E, Quemada HD. 2002. Diversity in free-living populations of Cucurbita pepo 
(Cucurbitaceae) as assessed by random amplified polymorphic DNA. Syst. Bot. 27:1928

Denno RF, McClure MS, Ott JR. 1995. Interspecific interactions in phytophagous insects - competition reexamined and resurrected. Annu. Rev. Entomol. 40:297-331

Dewar AM, May MJ, Pidgeon JD. 2004. Environmental impact of GM herbicide-tolerant crops: the UK Farm Scale Evaluations and proposal for mitigation. http://www.isb. vt.edu/news/2004/news04.Feb.html

Dunne JA, Williams RJ, Martinez ND. 2002. Network structure and biodiversity loss in food webs: robustness increases with connectance. Ecol. Lett. 5:558-67

Dunwell JM. 1999. Transgenic crops: the next generation, or an example to 2020 vision. Ann. Bot. 84:269-77

Eastham K, Sweet J. 2002. Genetically modified organisms (GMOs): the significance of gene flow through pollen transfer. Luxembourg: Off. Off. Publ. Eur. Communities. $75 \mathrm{pp}$.

Ellstrand NC. 2003. Dangerous Liaisons? When Cultivated Plants Mate with Their Wild Relatives. Baltimore, MD: Johns Hopkins Univ. Press. 244 pp.

Ellstrand NC, Prentice HC, Hancock JF. 1999. Gene flow and introgression from domesticated plants into their wild relatives. Annu. Rev. Ecol. Syst. 30:539-63

Ellstrand NC, Schierenbeck KA. 2000. Hybridization as a stimulus for the evolution of invasiveness in plants? Proc. Natl. Acad. Sci. USA 97:7043-50

Escher N, Käch B, Nentwig W. 2000. Decomposition of transgenic Bacillus thuringiensis maize by microorganisms and woodlice Porcellio scaber (Crustacea: Isopoda). Basic Appl. Ecol. 1:161-69

Fawcett R, Towery D. 2003. Conservation tillage and plant biotechnology: how new technologies can improve the environment by reducing the need to plow. http://www.ctic. purdue.edu/CTIC/BiotechPaper.pdf

Ferdy J-B, Austerlitz F. 2002. Extinction and introgression in a community of partially cross-fertile plant species. Am. Nat. 160:7486

Firbank LG, Heard MS, Woiwod IP, Hawes C, Haughton AJ, et al. 2003. An introduction to the Farm-Scale Evaluations of genetically modified herbicide-tolerant crops. J. Appl. Ecol. 40:2-16

Fischer R, Emans N. 2000. Molecular farming of pharmaceutical proteins. Transgenic Res. 9:279-99

Fuchs M, Gonsalves D. 1997. Risk assessment of gene flow associated with the release of virus-resistant transgenic crop plants. In Virus Resistant Transgenic Plants: Potential Ecological Impact, ed. M Tepfer, E Balazs, pp. 114-19. New York: Springer

Fuchs M, Gonsalves D. 1999. Risk assessment of gene flow from a virus-resistant transgenic squash into a wild relative. In Methods for Risk Assessment of Transgenic Plants: III. Ecological Risks and Prospects of Transgenic Plants, Where Do We Go From Here? A Dialogue Between Biotech Industry and Science, ed. K Ammann, Y Jacot, V Simonsen, G Kjellsson, pp. 141-43. Basel, Switz.: Birkhäuser-Verlag

Gebhard F, Smalla K. 1999. Monitoring field releases of genetically modified sugar beets for persistence of transgenic plant DNA and horizontal gene transfer. FEMS Microbiol. Ecol. 28:261-72

Gerlach JD, Rice KJ. 2003. Testing life history correlates of invasiveness using congeneric plant species. Ecol. Appl. 13:167-79

Ghassemi F, Jakeman AJ, Nix HA. 1995. Salinisation of Land and Water Resources: $\mathrm{Hu}$ man Causes, Extent, Management, and Case Studies. Oxfordshire, UK: CAB Int. 526 pp. Gianessi LP, Silvers CS, Sankula S, Carpenter JE. 2002. Plant biotechnology: current and potential impact for improving pest management in U.S. agriculture: an analysis of 40 case studies. http://www.ncfap.org/ 40CaseStudies.htm

GM Sci. Rev. Panel. 2003. GM Science Review (First Report): An open review of the science relevant to GM crops and food based on interests and concerns of the public. 
http://www.gmsciencedebate.org.uk/report/ pdf/gmsci-report1-full.pdf

GM Sci. Rev. Panel. 2004. GM Science Review (Second Report): An open review of the science relevant to GM crops and food based on interests and concerns of the public. http://www.gmsciencedebate.org.uk/report/ pdf/gmsci-report2-full.pdf

Gould F. 1998. Sustainability of transgenic insecticidal cultivars: integrating pest genetics and ecology. Annu. Rev. Entomol. 43:70126

Groot AT, Dicke M. 2002. Insect-resistant transgenic plants in a multi-trophic context. Plant J. 31:387-406

Gueritaine G, Sester M, Eber F, Chevre AM, Darmency H. 2002. Fitness of backcross six of hybrids between transgenic oilseed rape (Brassica napus) and wild radish (Raphanus raphanistrum). Mol. Ecol. 11:1419-26

Guretzky JA, Louda SM. 1997. Evidence for natural biological control: insects decrease survival and growth of a native thistle. Ecol. Appl. 7:1330-40

Hails RS. 2000. Genetically modified plantsthe debate continues. Trends Ecol. Evol. 15: 14-18

Halpin C, Boerjan W. 2003. Stacking transgenes in forest trees. Trends Plant Sci. 8:36365

Hammond J, Lecoq H, Raccah B. 1999. Epidemiological risks from mixed virus infections and transgenic plants expressing viral genes. Adv. Virus Res. 54:189-314

Hartl DL, Clark AG. 1997. Principles of Population Genetics. Sunderland, MA: Sinauer

Haughton AJ, Champion GT, Hawes C, Heard MS, Brooks DR, et al. 2003. Invertebrate responses to the management of genetically modified herbicide-tolerant and conventional spring crops. II. Within-field epigeal and aerial arthropods. Philos. Trans. R. Soc. London Ser. B 358:1863-77

Hawes C, Haughton AJ, Osborne JL, Roy DB, Clark SJ, et al. 2003. Responses of plants and invertebrate trophic groups to contrasting herbicide regimes in the Farm Scale Evaluations of genetically modified herbicide- tolerant crops. Philos. Trans. R. Soc. London Ser. B 358:1899-913

Haygood R, Ives AR, Andow DA. 2003. Consequences of recurrent gene flow from crops to wild relatives. Proc. R. Soc. London Ser. B 270:1879-86

Heard MS, Hawes C, Champion GT, Clark SJ, Firbank LG, et al. 2003a. Weeds in fields with contrasting conventional and genetically modified herbicide-tolerant crops. I. Effects on abundance and diversity. Philos. Trans. R. Soc. London Ser. B 358:1819-32

Heard MS, Hawes C, Champion GT, Clark SJ, Firbank LG, et al. 2003b. Weeds in fields with contrasting conventional and genetically modified herbicide-tolerant crops. II. Effects on individual species. Philos. Trans. R. Soc. London Ser. B 358:1833-46

Hellmich RL, Siegfried BD, Sears MK, Stanley-Horn DE, Daniels MJ, et al. 2001. Monarch larvae sensitivity to Bacillus thuringiensis purified proteins and pollen. Proc. Natl. Acad. Sci. USA 98:11925-30

Hilbeck A, Moar WJ, Pusztai-Carey M, Filippini A, Bigler F. 1998. Toxicity of Bacillus thuringiensis $\mathrm{Cry} 1 \mathrm{Ab}$ toxin to the predator Chrysoperla carnea (Neutoptera: Chrysopidae). Environ. Entomol. 27:1255-63

Hoffman AA, Blows MW. 1994. Species borders: ecological and evolutionary perspectives. Trends Ecol. Evol. 9:223-27

Hoffman MP, Zalom FG, Wilson LT, Smilanick JM, Malyj LD, et al. 1992. Field evaluation of transgenic tobacco containing genes encoding Bacillus thuringiensis delta-endotoxin or cowpea trypsin inhibitor: efficacy against Helicoverpa zea (Lepidoptera: Noctuidae). J. Econ. Entomol. 85:2516-22

Hopkins DW, Webster EA, Chudek JA, Halpin C. 2001. Decomposition in soil of tobacco plants with genetic modifications to lignin biosynthesis. Soil Biol. Biochem. 33:145562

Howard RD, DeWoody JA, Muir WM. 2004. Transgenic male mating advantage provides opportunity for Trojan gene effect in a fish. Proc. Natl. Acad. Sci. USA 101:2934-38 Hsieh TH, Lee JT, Charng YY, Chan MT. 2002. 
Tomato plants ectopically expressing Arabidopsis CBF1 show enhanced resistance to water deficit stress. Plant Physiol. 130:61826

Huxel GR. 1999. Rapid displacement of native species by invasive species: effects of hybridization. Biol. Conserv. 89:143-52

ISB. 2004a. Crops no longer regulated by USDA: approved and pending. http://www. isb.vt.edu/cfdocs/biopetitions1.cfm

ISB. 2004b. Workshop Report: Extending the net fitness model to considerations of crop gene flow. http://www.isb.vt.edu/news/ 2004/Jan04.pdf

James C. 2003. Preview: Global Status of Commercialized Transgenic Crops: 2003. ISAAA Briefs No. 30. Ithaca, NY: ISAAA

Jarosz AM, Davelos AL. 1995. Effects of disease in wild plant-populations and the evolution of pathogen aggressiveness. New Phytol. 129:371-87

Jaworski J, Cahoon EB. 2003. Industrial oils from transgenic plants. Curr. Opin. Plant Biol. 6:178-84

Jesse LCH, Obrycki JJ. 2000. Field deposition of $B t$ transgenic corn pollen: lethal effects on the monarch butterfly. Oecologia 125:24148

Kaeppler HF. 2000. Food safety assessment of genetically modified crops. Agron. J. 92: 793-97

Kay E, Vogel TM, Bertolla F, Nalin R, Simonet P. 2002. In situ transfer of antibiotic resistance genes from transgenic (transplastomic) tobacco plants to bacteria. Appl. Environ. Microbiol. 68:3345-51

Kirkpatrick KJ, Wilson HD. 1988. Interspecific gene flow in Cucurbita: C. texana vs. C. pepo. Am. J. Bot. 75:519-27

Kok EJ, Kuiper HA. 2003. Comparative safety assessment for biotech crops. Trends Biotechnol. 21:439-44

Kolar CS, Lodge DM. 2001. Progress in invasion biology: predicting invaders. Trends Ecol. Evol. 16:199-204

Kourtev PS, Ehrenfeld JG, Haggblom M. 2003. Experimental analysis of the effect of exotic and native plant species on the structure and function of soil microbial communities. Soil Biol. Biochem. 35:895-905

Kowalchuk GA, Bruinsma M, van Veen JA. 2003. Assessing responses of soil microorganisms to GM plants. Trends Ecol. Evol. 18: 403-10

Letourneau DK, Burrows BE, eds. 2002. Genetically Engineered Organisms: Assessing Environmental and Human Health Effects. Boca Raton, FL: CRC Press. 438 pp.

Letourneau DK, Hagen JA, Robinson GS. 2002. $B t$-crops: Evaluating benefits under cultivation and risks from escaped transgenes in the wild. See Letourneau \& Burrows 2002, pp. 33-98

Letourneau DK, Robinson GS, Hagen JA. 2003. Bt crops: predicting effects of escaped transgenes on the fitness of wild plants and their herbivores. Environ. Biosaf. Res. 2:219-46

Levin DA, Francisco-Ortega J, Jansen RK. 1996. Hybridization and the extinction of rare plant species. Conserv. Biol. 10:10-16

Linder CR, Taha I, Seiler GJ, Snow AA, Rieseberg LH. 1998. Long-term introgression of crop genes into wild sunflower populations. Theor. Appl. Genet. 96:339-47

Lonsdale WM. 1999. Global patterns of plant invasions and the concept of invasibility. Ecology 80:1522-36

Losey JE, Rayor LS, Carter ME. 1999. Transgenic pollen harms monarch larvae. Nature 399:214

Louda SM, Pemberton RW, Johnson MT, Follet PA. 2003. Non-target effects: the Achilles heel of biological control? Retrospective analyses to reduce risk associated with biocontrol introductions. Annu. Rev. Entomol. 48:365-96

Louda SM, Potvin MA. 1995. Effect of inflorescence-feeding insects on the demography and lifetime fitness of a native plant. Ecology 76:229-45

Ma JK-C, Pascal MWD, Christou P. 2003. The production of recombinant pharmaceutical proteins in plants. Nat. Rev. Genet. 4:794805

Mack RN, Simberloff D, Lonsdale WM, Evans H, Clout M, Bazzaz FA. 2000. Biotic 
invasions: causes, epidemiology, global consequences, and control. Ecol. Appl. 10:689710

Malone LA, Pham-Delègue M-H. 2001. Effects of transgene products on honey bees (Apis mellifera) and bumblebees (Bombus sp.). Apidologie 32:1-18

Mann CC. 2002. Has GM corn 'invaded' Mexico? Science 295:1617-18

Marquis RJ. 1992. The selective impact of herbivores. In Plant Resistance to Herbivores and Pathogens: Ecology, Evolution, and Genetics, ed. RS Fritz, EL Simms, pp. 301-25. Chicago: Univ. Chicago Press

Martinez-Ghersa MA, Worster CA, Radosevich SR. 2003. Concerns a weed scientist might have about herbicide-tolerant crops: a revisitation. Weed Technol. 17:202-10

Marvier MA. 2001. Ecology of transgenic crops. Am. Sci. 89:160-67

Maskell LC, Raybould AF, Cooper JI, Edwards ML, Gray AJ. 1999. Effects of turnip mosaic virus and turnip yellow mosaic virus on the survival, growth and reproduction of wild cabbage (Brassica oleracea). Ann. Appl. Biol. 135:401-7

Mason P, Braun L, Warwick SI, Zhu B, Stewart CN Jr. 2003. Transgenic Bt-producing Brassica napus: Plutella xylostella selection pressure and fitness of weedy relatives. Environ. Biosaf. Res. 2:236-76

Maynard Smith J, Haigh J. 1974. The hitchhiking effect of a favourable gene. Genet. Res. 23:23-35

Meagher TR, Belanger FC, Day PR. 2003. Using empirical data to model transgene dispersal. Philos. Trans. R. Soc. London Ser. B 358:1157-62

Mellon M, Rissler J. 2004. Gone to Seed: Transgenic Contaminants in the Traditional Seed Supply. Cambridge, MA: Union Concerned Sci. 70 pp.

Mendelsohn M, Kough J, Vaituzis Z, Matthews K. 2003. Are Bt crops safe? Nat. Biotechnol. 21:1003-9

Mitchell CE, Power AG. 2003. Release of invasive plants from fungal and viral pathogens. Nature 421:625-27
Moar WJ. 2003. Breathing new life into insectresistant plants. Nat. Biotechnol. 21:1152-54 Muir WM, Howard RD. 1999. Possible ecological risks of transgenic organism release when transgenes affect mating success: sexual selection and the Trojan gene hypothesis. Proc. Natl. Acad. Sci. USA 96:13853-56

Muir WM, Howard RD. 2001. Fitness components and ecological risk of transgenic release: a model using Japanese Medaka (Oryzias latipes). Am. Nat. 158:1-16

Muir WM, Howard RD. 2002. Assessment of possible ecological risks and hazards of transgenic fish with implications for other sexually reproducing organisms. Transgenic Res. 11:101-14

Natl. Res. Counc. (NRC). 1986. Pesticide Resistance: Strategies and Tactics for Management. Washington, DC: Natl. Acad. Press. $471 \mathrm{pp}$.

Natl. Res. Counc. (NRC). 2000. Genetically Modified Pest-Protected Plants: Science and Regulation. Washington, DC: Natl. Acad. Press. 292 pp.

Natl. Res. Counc. (NRC). 2002a. Environmental Effects of Transgenic Plants: The Scope and Adequacy of Regulation. Washington, DC: Natl. Acad. Press. 342 pp.

Natl. Res. Counc. (NRC). 2002b. Predicting Invasions of Nonindigenous Plants and Plant Pests. Washington, DC: Natl. Acad. Press. 194 pp.

Natl. Res. Counc. (NRC). 2004. Biological Confinement of Genetically Engineered Organisms. Washington, DC: Natl. Acad. Press. $236 \mathrm{pp}$.

Nielsen KM, Bones AM, Smalla K, van Elsas JD. 1998. Horizontal gene transfer from transgenic plants to terrestrial bacteria-a rare event? FEMS Microbiol. Rev. 22:79-103

Nielsen KM, Gebhard F, Smalla K, Bones AM, van Elsas JD. 1997. Evaluation of possible horizontal gene transfer from transgenic plants to the soil bacterium Acinetobacter calcoaceticus BD413. Theor. Appl. Genet. 95:815-21

Nielsen KM, Smalla K, van Elsas JD. 2000a. Natural transformation of Acinetobacter sp. 
strain BD413 with cell lysates of Acinetobacter sp., Pseudomonas fluorescens, and Burkholderia cepacia in soil microcosms. Appl. Environ. Microbiol. 66:206-12

Nielsen KM, van Elsas JD, Smalla K. 2000b. Transformation of Acinetobacter sp. strain BD413(pFG4 nptII) with transgenic plant DNA in soil microcosms and effects of kanamycin on selection of transformants. Appl. Environ. Microbiol. 66:1237-42

Nielsen KM, van Elsas JD, Smalla K. 2001. Dynamics, horizontal transfer and selection of novel DNA in bacterial populations in the phytosphere of transgenic plants. Ann. Microbiol. 51:79-94

Oberhauser KS, Prysby MD, Mattila HR, Stanley-Horn DE, Sears MK, et al. 2001. Temporal and spatial overlap between monarch larvae and corn pollen. Proc. Natl. Acad. Sci. USA 98:11913-18

Obrycki JJ, Losey JE, Taylor OR, Jesse LCH. 2001. Transgenic insecticidal corn: beyond insecticidal toxicity to ecological complexity. BioScience 51:353-61

Oerke E-C, Dehne H-W, Schönbeck F, Weber A. 1994. Crop Production and Crop Protection: Estimated Losses in Major Food and Cash Crops. Amsterdam: Elsevier Sci. B.V. 808 pp.

Orr DB, Landis DA. 1997. Oviposition of European corn borer (Lepidoptera: Pyralidae) and impact of natural enemy populations in transgenic versus isogenic corn. J. Econ. Entomol. 90:905-9

Parker IM, Kareiva P. 1996. Assessing the risks of invasion for genetically engineered plants: Acceptable evidence and reasonable doubt. Biol. Conserv. 78:193-203

Pessel FD, Lecomte J, Emeriau V, Krouti M, Messean A, Gouyon PH. 2001. Persistence of oilseed rape (Brassica napus L.) outside of cultivated fields. Theor. Appl. Genet. 102:841-46

Pilcher CD, Obrycki JJ, Rice ME, Lewis LC. 1997. Preimaginal development, survival, and field abundance of insect predators on transgenic Bacillus thuringiensis corn. Environ. Entomol. 26:446-54
Pilson D. 2000. Herbivory and natural selection on flowering phenology in wild sunflower, Helianthus annuus. Oecologia 122:72-82

Pilson D, Decker KL. 2002. Compensation for herbivory in wild sunflower: response to simulated damage by the head-clipping weevil. Ecology 83:3097-107

Pilson D, Snow AA, Rieseberg LH, Alexander HM. 2004. A protocol for evaluating the ecological risks associated with gene flow from transgenic crops into their wild relatives: the case of cultivated sunflower and wild $\mathrm{He}$ lianthus annuus. In Introgression from $\mathrm{Ge}$ netically Modified Plants into Wild Relatives, ed. HCM den Nijs, D Bartsch, J Sweet, pp. 219-33. Oxfordshire, UK: CAB Int.

Pleasants JM, Hellmich RL, Dively GP, Sears MK, Stanley-Horn DE, et al. 2001. Corn pollen deposition on milkweeds in and near cornfields. Proc. Natl. Acad. Sci. USA 98:11919-24

Polis GA, Strong DR. 1996. Food web complexity and community dynamics. Am. Nat. 147:813-46

Poppy G. 2000. GM crops: environmental risks and non-target effects. Trends Plant Sci. 5:46

Power AG. 2002. Ecological risks of transgenic virus-resistant crops. See Letourneau \& Burrows 2002, pp. 125-42

Pray CE, Huang JK, Hu R, Rozelle S. 2002. Five years of $B t$ cotton in China-the benefits continue. Plant J. 31:423-30

Quist D, Chapela IH. 2001. Transgenic DNA introgressed into traditional maize landraces in Oaxaca, Mexico. Nature 414:541-43

Quist D, Chapela IH. 2002. Reply. Nature 416:602

Rhymer JM, Simberloff D. 1996. Extinction by hybridization and introgression. Annu. Rev. Ecol. Syst. 27:89-109

Riddick EW, Dively G, Barbosa P. 1998. Effect of a seed-mix deployment of Cry3Atransgenic and nontransgenic potato on the abundance of Lebia grandis (Coleoptera: Carabidae) and Coleomegilla maculata (Coleoptera: Coccinellidae). Ann. Entomol. Soc. Am. 91:647-53 
Rieseberg LH, Baird SJE, Gardner KA. 2000. Hybridization, introgression, and linkage evolution. Plant Mol. Biol. 42:205-24

Rieseberg LH, Kim MJ, Seiler GJ. 1999. Introgression between cultivated sunflower and a sympatric wild relative, Helianthus petiolaris (Asteraceae). Int. J. Plant Sci. 160:1028

Rieseberg LH, Wendel JF. 1993. Introgression and its consequences in plants. In Hybrid Zones and the Evolutionary Process, ed. $\mathrm{R}$ Harrison, pp. 70-109. New York: Oxford Univ. Press

Rieseberg LH, Widmer A, Arntz MA, Burke JM. 2003. The genetic architecture necessary for transgressive segregation is common in both natural and domesticated populations. Philos. Trans. R. Soc. London Ser. B 358:1141-47

Rissler J, Mellon M. 1996. The Ecological Risks of Engineered Crops. Cambridge, MA: MIT Press. 168 pp.

Roossinck MJ. 1997. Mechanisms of plant virus evolution. Annu. Rev. Phytopathol. 35:191209

Roy DB, Bohan DA, Haughton AJ, Hill MO, Osborne JL, et al. 2003. Invertebrates and vegetation of field margins adjacent to crops subject to contrasting herbicide regimes in the Farm Scale Evaluations of genetically modified herbicide-tolerant crops. Philos. Trans. R. Soc. London Ser. B 358:1879-98

Royal Society. 2002. Genetically modified plants for food use and human healthan update. http://www.royalsoc.ac.uk/files/ statfiles/document-165.pdf

Rubio T, Borja M, Scholthof HB, Jackson AO. 1999. Recombination with host transgenes and effects on virus evolution: an overview and opinion. Mol. Plant Microbe. Interact. 12:87-92

Sakai AK, Allendorf FW, Holt JS, Lodge DM, Molofsky J, et al. 2001. The population biology of invasive species. Annu. Rev. Ecol. Syst. 32:305-32

Saxena D, Flores S, Stotzky G. 1999. Insecticidal toxin in root exudates from $B t$ corn. Nature 402:480
Saxena D, Stotzky G. 2001. Bacillus thuringiensis $(B t)$ toxin released from root exudates and biomass of $B t$ corn has no apparent effect on earthworms, nematodes, protozoa, bacteria, and fungi in soil. Soil Biol. Biochem. 33:1225-30

Schlüter K, Fütterer J, Potrykus I. 1995. "Horizontal" gene transfer from a transgenic potato line to a bacterial pathogen ( $E r$ winia chrysanthemi) occurs-if at all-at an extremely low frequency. BioTechnology 13:1094-98

Schuler TH, Poppy GM, Kerry BR, Denholm I. 1999. Potential side effects of insect-resistant transgenic plants on arthropod natural enemies. Trends Biotechnol. 17:210-16

Sears MK, Hellmich RL, Stanley-Horn DE, Oberhauser KS, Pleasants JM, et al. 2001. Impact of $B t$ corn pollen on monarch butterfly populations: a risk assessment. Proc. Natl. Acad. Sci. USA 98:11937-42

Shelton AM, Tang JD, Roush RT, Metz TD, Earle ED. 2000. Field tests on managing resistance to $B t$-engineered plants. Nat. Biotechnol. 18:339-42

Shelton AM, Zhao JZ, Roush RT. 2002. Economic, ecological, food safety, and social consequences of $B t$ transgenic plants. Annu. Rev. Entomol. 47:845-81

Silvertown J, Franco M, Pisanty I, Mendoza A. 1993. Comparative plant demographyrelative importance of life-cycle components to the finite rate of increase in woody and herbaceous perennials. J. Ecol. 81:465-76

Simms EL, Rausher MD. 1987. Costs and benefits of plant resistance to herbivory. Am. Nat. 130:570-81

Sinclair TR, Purcell LC, Sneller CH. 2004. Crop transformation and the challenge to increase yield potential. Trends Plant Sci. 9: 70-75

Snow AA, Andersen B, Jørgensen RB. 1999. Costs of transgenic herbicide resistance introgressed from Brassica napus into weedy B. rapa. Mol. Ecol. 8:605-15

Snow AA, Andow DA, Gepts P, Hallerman EM, Power A, et al. 2004. Genetically engineered organisms and the environment: current 
status and recommendations. http://www. esa.org/pao/esaPositions/Papers/geo_position. htm

Snow AA, Moran-Palma P. 1997. Commercialization of transgenic plants: potential ecological risks. BioScience 47:86-96

Snow AA, Moran-Palma P, Rieseberg LH, Wszelaki A, Seiler GJ. 1998. Fecundity, phenology, and seed dormancy of F-1 wild-crop hybrids in sunflower (Helianthus annuus, Asteraceae). Am. J. Bot. 85:794-801

Snow AA, Pilson D, Rieseberg LH, Paulsen MJ, Pleskac N, et al. 2003. A Bt transgene reduces herbivory and enhances fecundity in wild sunflowers. Ecol. Appl. 13:279-86

Spencer LJ, Snow AA. 2001. Fecundity of transgenic wild-crop hybrids of Cucurbita pepo (Cucurbitaceae): implications for cropto-wild gene flow. Heredity 86:694-702

Squire GR, Brooks DR, Bohan DA, Champion GT, Daniels RE, et al. 2003. On the rationale and interpretation of the Farm Scale Evaluations of genetically modified herbicidetolerant crops. Philos. Trans. R. Soc. London Ser. B 358:1779-99

Stanley-Horn DE, Dively GP, Hellmich RL, Mattila HR, Sears MK, et al. 2001. Assessing the impact of Cry $1 \mathrm{Ab}$-expressing corn pollen on monarch butterfly larvae in field studies. Proc. Natl. Acad. Sci. USA 98:11931-36

Stewart CN Jr, Halfhill MD, Warwick SI. 2003. Transgene introgression from genetically modified crops to their wild relatives. Nat. Rev. Genet. 4:806-17

Tabashnik BE. 1994. Evolution of resistance to Bacillus thuringiensis. Annu. Rev. Entomol. 39:47-79

Tabashnik BE, Carrière Y, Dennehy TJ, Morin S, Sisterson MS, et al. 2003. Insect resistance to transgenic Bt crops: lessons from the laboratory and field. J. Econ. Entomol. 96:103138

Takahashi M, Nakanishi H, Kawasaki S, Nichizawa NK, Mori S. 2001. Enhanced tolerance of rice to low iron availability in alkaline soils using barley nicotianamine aminotransferase genes. Nat. Biotechnol. 19:46669
Tepfer M. 2002. Risk assessment of virusresistant transgenic plants. Annu. Rev. Phytopathol. 40:467-91

Thompson CJ, Thompson BJP, Ades PK, Cousens R, Garnier-Gere P, et al. 2003. Model-based analysis of the likelihood of gene introgression from genetically modified crops into wild relatives. Ecol. Model. 162:199-209

Thomson J. 2003. Genetically modified food crops for improving agricultural practice and their effects on human health. Trends Food Sci. Technol. 14:210-12

Tiedje JM, Colwell RK, Grossman YL, Hodson RE, Lenski RE, et al. 1989. The planned introduction of genetically engineered organisms: ecological considerations and recommendations. Ecology 70:298-315

Wardle DA. 2002. Communities and Ecosystems: Linking the Aboveground and Belowground Components. Princeton, NJ: Princeton Univ. Press. 392 pp.

Warwick SI, Beckie HJ, Small E. 1999. Transgenic crops: new weed problems for Canada? Phytoprotection 80:71-84

Warwick SI, Simard M-J, Légère A, Beckie HJ, Braun L, et al. 2003. Hybridization between transgenic Brassica napus L. and its wild relatives: Brassica rapa L., Raphanus raphanistrum L., Sinapis arvensis L., and Erucastrum gallicum (Willd). O.E. Schulz. Theor. Appl. Genet. 107:528-39

Watkinson AR, Freckleton RP, Robinson RA, Sutherland WJ. 2000. Predictions of biodiversity response to genetically modified herbicide-tolerant crops. Science 289:155457

Whitton J, Wolf DE, Arias DM, Snow AA, Rieseberg LH. 1997. The persistence of cultivar alleles in wild populations of sunflowers five generations after hybridization. Theor. Appl. Genet. 95:33-40

Willis AJ, Memmott J, Forrester RI. 2000. Is there evidence for the post-invasion evolution of increased size among invasive plant species? Ecol. Lett. 3:275-83

Willis AJ, Thomas MB, Lawton JH. 1999. Is the increased vigour of invasive weeds explained 
by a trade-off between growth and herbivore resistance? Oecologia 120:632-40

Wilson HD. 1993. Free-living Cucurbita pepo in the United States: viral resistance, gene flow, and risk assessment. USDA Anim. Plant Health Insp. Serv., Hyattsville, MD

Wolf DE, Takebayashi N, Rieseberg LH. 2001. Predicting the risk of extinction through hybridization. Conserv. Biol. 15:103953

Wolfenbarger LL, Phifer PR. 2000. The ecological risks and benefits of genetically engineered plants. Science 290:2088-93

Wraight CL, Zangerl AR, Carroll MJ, Berenbaum MR. 2000. Absence of toxicity of Bacillus thuringiensis pollen to black swallowtails under field conditions. Proc. Natl. Acad. Sci. USA 97:7700-3
Zangerl AR, McKenna D, Wraight CL, Carroll M, Ficarello P, et al. 2001. Effects of exposure to event 176 Bacillus thuringiensis corn pollen on monarch and black swallowtail caterpillars under field conditions. Proc. Natl. Acad. Sci. USA 98:11908-12

Zhang H-X, Hodson JN, Williams JP, Blumwald E. 2001. Engineering salt-tolerant Brassica plants: characterization of yield and seed oil quality in transgenic plants with increased vacuolar sodium accumulation. Proc. Natl. Acad. Sci. USA 98:1283236

Zhang NY, Linscombe S, Oard J. 2003. Outcrossing frequency and genetic analysis of hybrids between transgenic glufosinate herbicide-resistant rice and the weed, red rice. Euphytica 130:35-45 